\title{
Gas Permeation of Sulfur Thin-Films and Potential as a Barrier Material
}

\author{
Xicheng Jia ${ }^{1}$, Thomas D. Bennett ${ }^{2, *} \mathbb{C}$ and Matthew G. Cowan ${ }^{1, * \mathbb{C}}$ \\ 1 Department of Chemical and Process Engineering, University of Canterbury, Christchurch 8041, \\ New Zealand; xicheng.jia@pg.canterbury.ac.nz \\ 2 Department of Materials Science and Metallurgy, University of Cambridge, Cambridge CB3 OFS, UK \\ * Correspondence: Tdb35@cam.ac.uk (T.D.B.); matthew.cowan@canterbury.ac.nz (M.G.C.); \\ Tel.: +44-01223-334329 (T.D.B.); +64-3369-2521 (M.G.C.)
}

Received: 31 May 2019; Accepted: 12 June 2019; Published: 14 June 2019

check for updates

\begin{abstract}
Elemental sulfur was formed into poly(ether sulfone)-supported thin-films (ca. $10 \mu \mathrm{m})$ via a melt-casting process. Observed permeabilities of $\mathrm{C}_{2} \mathrm{H}_{4}, \mathrm{CO}_{2}, \mathrm{H}_{2}, \mathrm{He}$, and $\mathrm{N}_{2}$ through the sulphur thin-films were $<1$ barrer. The sulfur thin-films were observed to age over a period of ca. 15 days, related to the reversion of polymerized sulfur to the $S_{8}$ allotrope. This structural conversion was observed to correlate with an increase in the permeability of all gases.
\end{abstract}

Keywords: sulfur; barrier materials; gas permeation; thin-films

\section{Introduction}

Elemental sulfur is produced as a by-product of petroleum refining and gas reserves using the hydrodesulfurization process [1]. Sulfur production is estimated at over 70 million tons each year [2], with over half the global supply produced in China, USA, Russia, Canada, and Saudi Arabia [3]. The majority of this sulfur is used in the production of sulfuric acid (more sulfuric acid is produced in the USA than any other chemical) [4,5], phosphate fertilizers [5,6], batteries [7], and in the vulcanization of natural and synthetic rubbers [8].

Elemental sulfur is usually present as a small cyclic molecule $\left(\mathrm{S}_{8}\right)$, i.e., an 8-ring configuration, under ambient conditions. However, a variety of cyclic and polymeric allotropes also exist $[9,10]$. Depending on the allotrope mixture, "pure" sulfur can melt at temperatures between 112 and $130{ }^{\circ} \mathrm{C}$. When liquid sulfur is heated above $159.4^{\circ} \mathrm{C}$, a discontinuity in physical properties is observed due to the polymerization of sulfur chains $[9,10]$. From the melt mixture, polymeric sulfur (yellow) and cyclic $\mathrm{S}_{8}$ rings (white) can be obtained depending on cooling conditions [9]. Above ca. $200{ }^{\circ} \mathrm{C}$, sulfur takes on a dark red hue due to the presence of organic impurities or highly reactive $S_{3}, S_{4}$, and $S_{5}$ species [9]. Upon cooling, sulfur slowly reverts to the thermodynamically stable $S_{8}$ allotrope [11].

Sulfur is largely considered as a by-product, with commodity value, trading below US\$68-109/ton [5]. This low value has resulted in efforts to derive value-added products from bulk-sulfur $[10,12,13]$. Since 2013, the "inverse vulcanization" process has shown promise in opening a synthetic route to sulfur-derived materials. Elemental sulfur in the liquid state is polymerized using the addition of vinyl monomers $[14,15]$. The resultant polymers are stable against recrystallization, can be self-healing [16-18], and have received considerable attention for application in battery electrodes [19-21]. Minor attention has been given to other applications such as the removal of mercury [22-24] and iron [25], anti-microbial materials [26], concrete and mortars [27], infrared optics [16,28-30], controlled release fertilizers [31], and oil spill clean-up [32].

The gas transport potential of sulfur-based materials remains, however, unexplored. As a dense material, thin-films of sulfur have potential to act as a barrier material. Key applications 
of barrier materials include low oxygen permeance to preserve the quality and taste of beverages and food, building construction, and hydrogen storage containers [33]. For barrier materials, the key materials-property goals are the ability to produce defect-free films, with low free volume [34], low molecule or polymeric chain mobility, and high density [33]. In general, materials with higher crystallinity make better barrier materials because the crystallite regions are impermeable-except along defects within the structure. However, high crystallinity is usually associated with brittleness and other non-desirable mechanical properties. There is one example of elemental sulfur being used in the synthesis of microporous polymers for application as adsorbents for natural gas sweetening [35]. However, our literature searching to date (ESI Section S1) suggests that the gas transport properties of elemental sulfur have not been characterized and it has not been considered as a barrier material. Herein, we present the gas permeability of sulfur thin-films when exposed to a selection of common gases $\left(\mathrm{C}_{2} \mathrm{H}_{4}, \mathrm{CO}_{2}, \mathrm{H}_{2}, \mathrm{He}\right.$, and $\left.\mathrm{N}_{2}\right)$ to provide baseline data for the comparison of sulfur-derived polymeric materials.

\section{Materials and Methods}

\subsection{Materials and Instrumentation}

All manipulations were carried out under an atmosphere inside a fume hood at a temperature of $21{ }^{\circ} \mathrm{C}$. Sulfur $\left(\mathrm{S}_{8}\right.$, sublimed flower, reagent grade, $\left.\geq 99.5 \%\right)$ was purchased from B.D.H. Laboratory Chemicals (Poole, England). Supor ${ }^{\circledR}$ hydrophilic poly(ether sulfone) disc filters (70\% porous) with a diameter of $47 \mathrm{~mm}$, were used as a support material and purchased from Pall Corporation (Port Washington, NY, USA). $\mathrm{CO}_{2}, \mathrm{~N}_{2}, \mathrm{H}_{2}, \mathrm{He}$, and $\mathrm{C}_{2} \mathrm{H}_{4}$ gas cylinders with purities of $\geq 99.99 \%$ were purchased from BOC (Auckland, New Zealand). The Powder X-ray diffraction (PXRD) patterns of the samples were recorded using a SmartLab X-Ray Diffractometer (Rigaku, Tokyo, Japan) equipped with a Co-K $\alpha$ radiation source. The specific surface area was measured by $\mathrm{N}_{2}$ adsorption/desorption measurements at $77 \mathrm{~K}$ using a Gemini VI surface area and pore analyzer. Scanning electron microscopic (SEM) images were obtained using a JEOL 700F scanning electron microscope (JEOL Ltd., Tokyo, Japan), and the corresponding energy dispersive X-ray spectroscopy (EDX) elemental mapping of sulfur was obtained by the same device. Thermogravimetric analysis and differential thermal analysis (TGA/DTA) were performed using a STA 449 F3 model from NETZSCH (Selb, Germany) with the TGA/DTA programmed as follows: equilibrate to $50{ }^{\circ} \mathrm{C}$, then ramp to $300{ }^{\circ} \mathrm{C}$ at $10{ }^{\circ} \mathrm{C} / \mathrm{min}$ under an $\mathrm{N}_{2}$ environment.

\subsection{Synthesis of the Sulfur Membrane}

A mass of $0.5 \mathrm{~g}$ of sulfur powder was transferred to a glass dish with a diameter of $55 \mathrm{~mm}$, which was pre-heated to $175^{\circ} \mathrm{C}$ on a hot plate (IKA ${ }^{\circledR}$ RCT basic, Staufen, Germany). After the sulfur powder melted and its color turned to dark red, the viscosity of the polymerized sulfur was observed to decrease. Thereafter, one side of the support material was briefly immersed within the sulfur melt and removed when a visually uniform layer of sulfur was generated over the support. The resultant sulfur-coated membrane was removed, and cooled for $10 \mathrm{~min}$ at room temperature, before being used for further experiments. SEM imaging showed that defect-free layers of sulfur of approximately $10 \mu \mathrm{m}$ were routinely produced.

\subsection{Single-Gas Permeability Test}

Single-gas $\mathrm{CO}_{2}, \mathrm{~N}_{2}, \mathrm{H}_{2}, \mathrm{He}$, and $\mathrm{C}_{2} \mathrm{H}_{4}$ permeability measurements were performed using a dead-end filtration unit similar to those reported in the literature $[36,37]$ and schematically shown in Figure 1. Experiments were performed at room temperature $\left(21^{\circ} \mathrm{C}\right)$ for $15 \mathrm{~h}$, and each gas was tested in triplicate for each membrane sample. Between experiments, the apparatus and membrane were evacuated for $5 \mathrm{~h}$ at room temperature using a dynamic vacuum of $<0.1$ torr. 


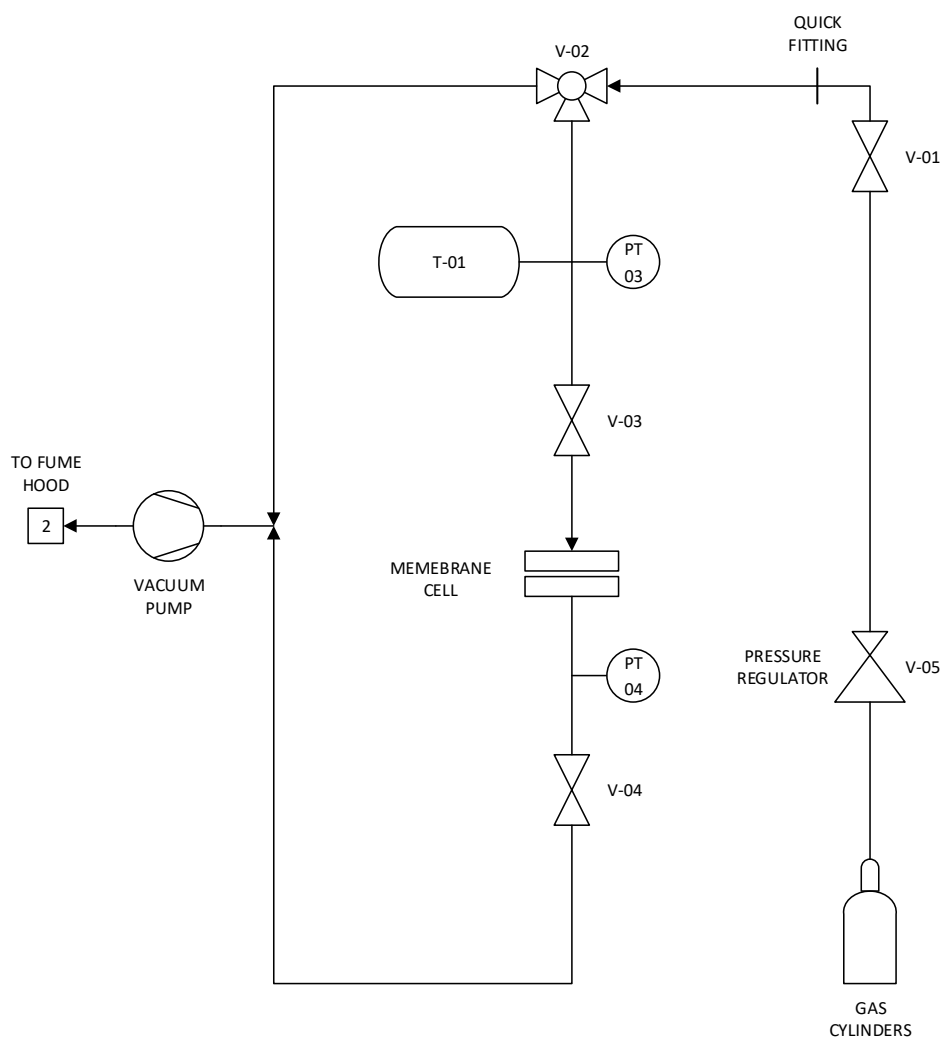

Figure 1. The dead-end filtration experimental set-up for measurement of single-gas permeability.

\section{Results and Discussion}

\subsection{Check of Sulfur Physio-Chemical Properties}

The aim of this study was to provide baseline data for the comparison of sulfur derived polymeric materials. Therefore, we aimed to measure the gas permeability of polymeric sulfur. Thermogravimetric analysis (TGA), differential thermal analysis (DTA), and the differential (DDTA) were measured to characterize the thermal properties of the sulfur used in this study (Figure 2) and ensure behavior conformed to that previously reported $[9,10]$. As expected, complex melt behavior was observed from ca. $103-150{ }^{\circ} \mathrm{C}$, followed by a discontinuity at ca. $175{ }^{\circ} \mathrm{C}$ related to the polymerization of sulfur chains. Casting of sulfur membranes was therefore performed at temperatures $\geq 175^{\circ} \mathrm{C}$. It was noted that at these temperatures, the sulfur became considerably less viscous and relatively easy to cast $[9,10]$. 


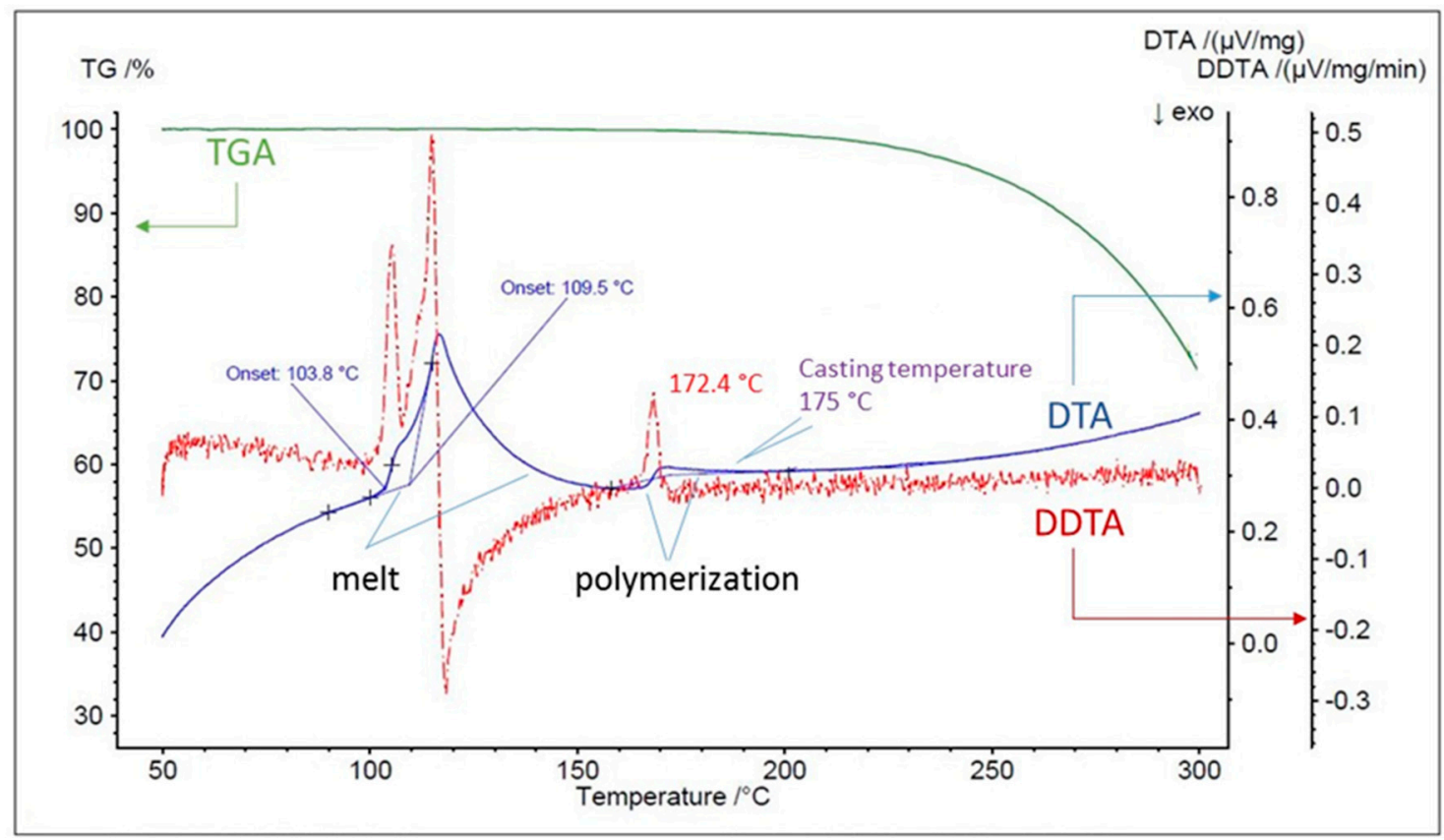

Figure 2. Thermogravimetric analysis (TGA), differential thermal analysis (DTA) and the differential (DDTA) spectra of the elemental sulfur up to $300^{\circ} \mathrm{C}$. (Green: TGA, Blue: DTA, and Red: DDTA).

\subsection{Preparation of Thin-Film Sulfur Membranes}

Free-standing thick films of sulfur were prepared by casting molten sulfur on glass, Teflon, and aluminum foil surfaces. The free-standing films could be masked using adhesive tinfoil. However, our attempts to measure the permeability of $>250 \mu \mathrm{m}$ thick sulfur membranes was frustrated by the low permeability of sulfur, resulting in membrane permeances too low to measure using our experimental set-up. In an effort to generate thinner films, we submerged porous supports of hydrophilic and hydrophobic poly(tetrafluoroethylene) and poly(ether sulfone) (PES) in molten sulfur. Of the studied supports, PES was found to be the most suitable support material, retaining both shape and physical integrity. This method generated films with thicknesses of $150 \mu \mathrm{m}$. These thicknesses were then reduced further by using a dip-coating method, where only the surface of the support was submerged in the molten sulfur. This proved successful for reproducibly, preparing membrane materials with cohesive defect-free active layers of ca. $\geq 10 \mu \mathrm{m}$ within poly(ether sulfone) supports (Figure 3), as confirmed by scanning electron microscopy (SEM) cross-sections (Figure 4) and top and bottom views (Figure 5). Although fragile to handle, these films were sufficiently robust for masking with adhesive aluminum foil and permeability testing with ca. $1 \mathrm{~atm}$ transmembrane pressure. The films are brittle and prone to cracking if handled indelicately and more robust materials would be advantageous for applied research.
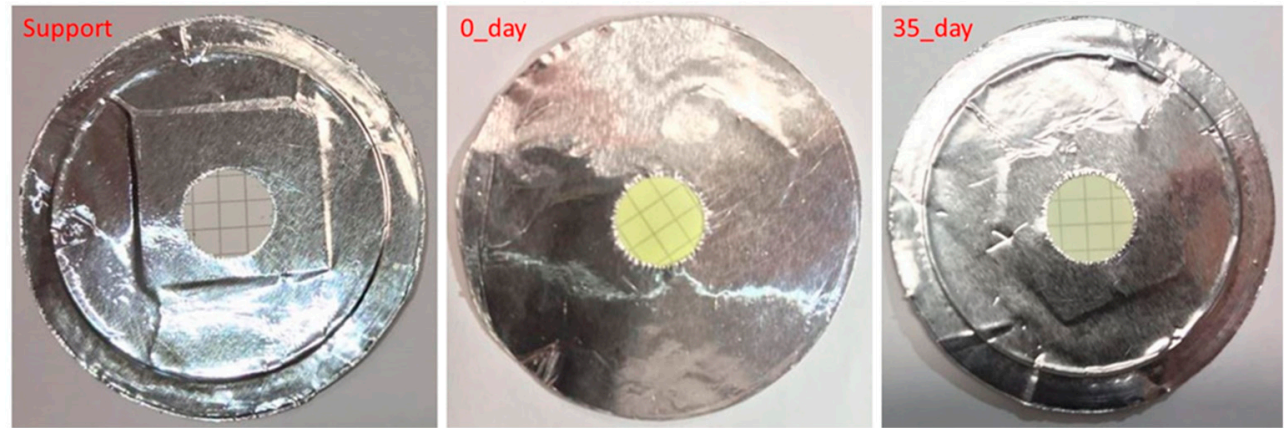

Figure 3. Images of the masked poly(ether sulfone) (PES) support (left), sulfur thin-film immediately after preparation (middle), and after membrane testing lasting ca. 35 days (right). Note the whitening of the aged membrane, suggestive of reversion of the polymeric sulfur to the $S_{8}$ species. 


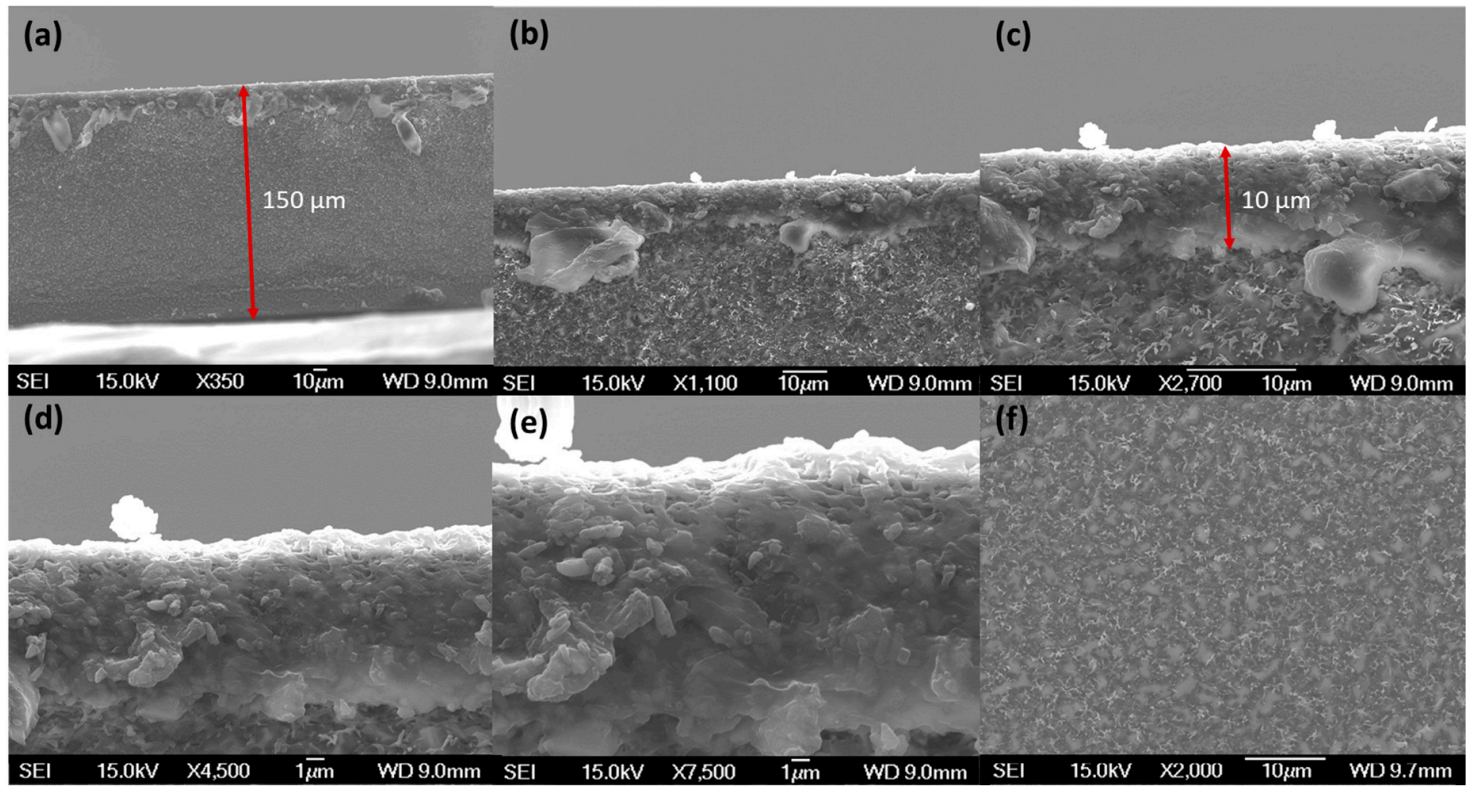

Figure 4. Scanning electron microscopic (SEM) images of cross sections of supported sulfur membranes prepared via dip coating: (a) full support with sulfur layer on top, (b) to (e) enlarged magnificatoin of $\geq 10 \mu \mathrm{m}$ sulfur film, and (f) the empty PES support.

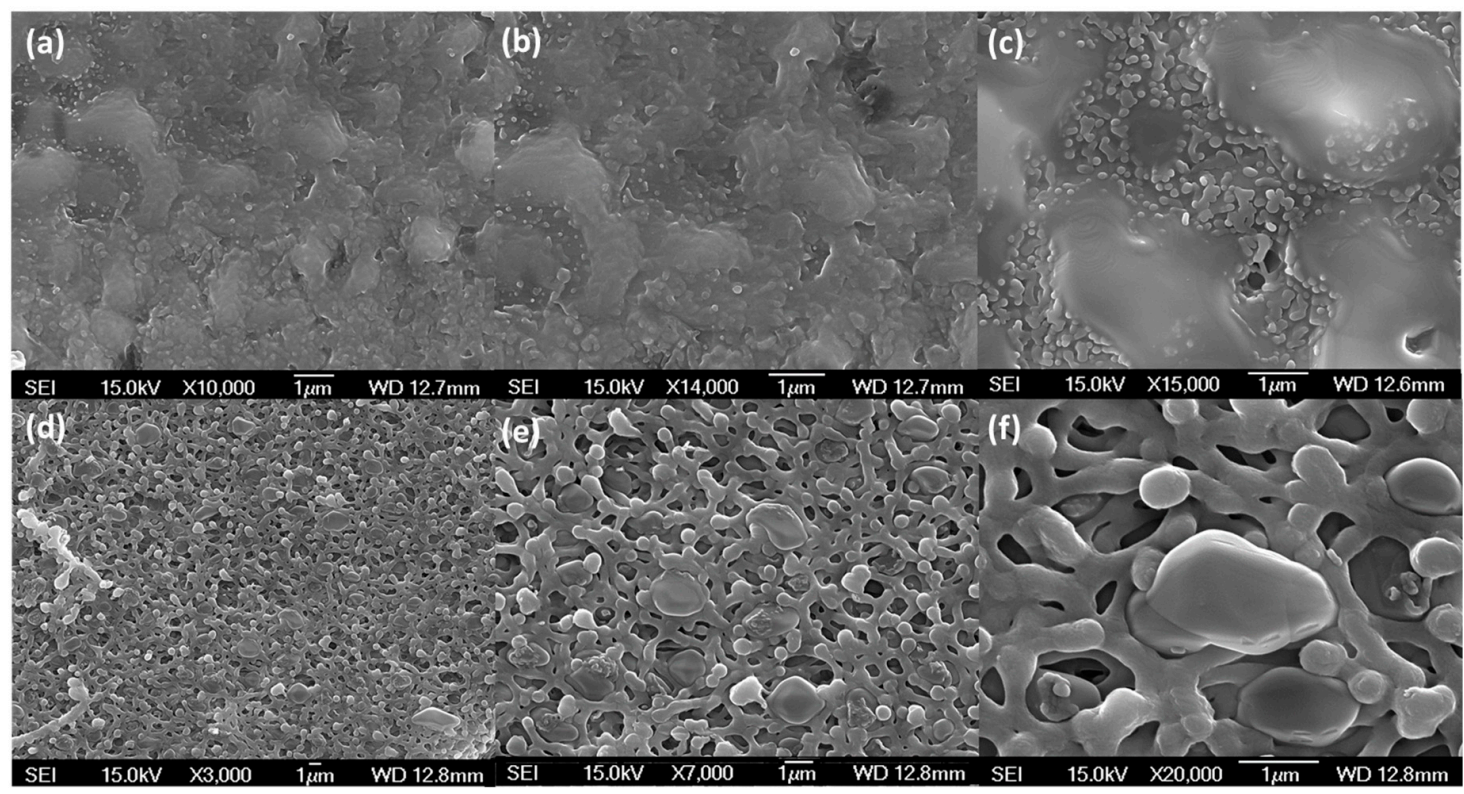

Figure 5. SEM images of the top and bottom surfaces of supported sulfur membranes prepared via dip-coating: (a-c) top-coating sulfur film and (d-f) open PES support.

It has been well-documented that polymerized sulfur slowly reverts to the $S_{8}$ species $[9,10,38]$. We used powder X-ray diffraction (PXRD) to monitor this progression over time. Baseline PXRD data for the blank supports, free-standing sulfur, and supported thin-films are shown in the ESI (Figures S3 and S4). The four peaks observed between $23-30^{\circ}$ correspond to PXRD previously reported for polymeric sulfur [39]. As shown in Figure 6, the PXRD pattern of the sulfur films is largely consistent to ca. 10 days, after which changes in the PXRD pattern, such as the re-emergence of the peak at ca. $20^{\circ}$ and development of fine structure between $30^{\circ}$ and $60^{\circ}$ show a change in the organization of the underlying material. As described in Section 3.3, these structural changes (likely associated with the reversion of polymerized sulfur to the $S_{8}$ allotrope) were related to increases in permeability of the thin-films. 


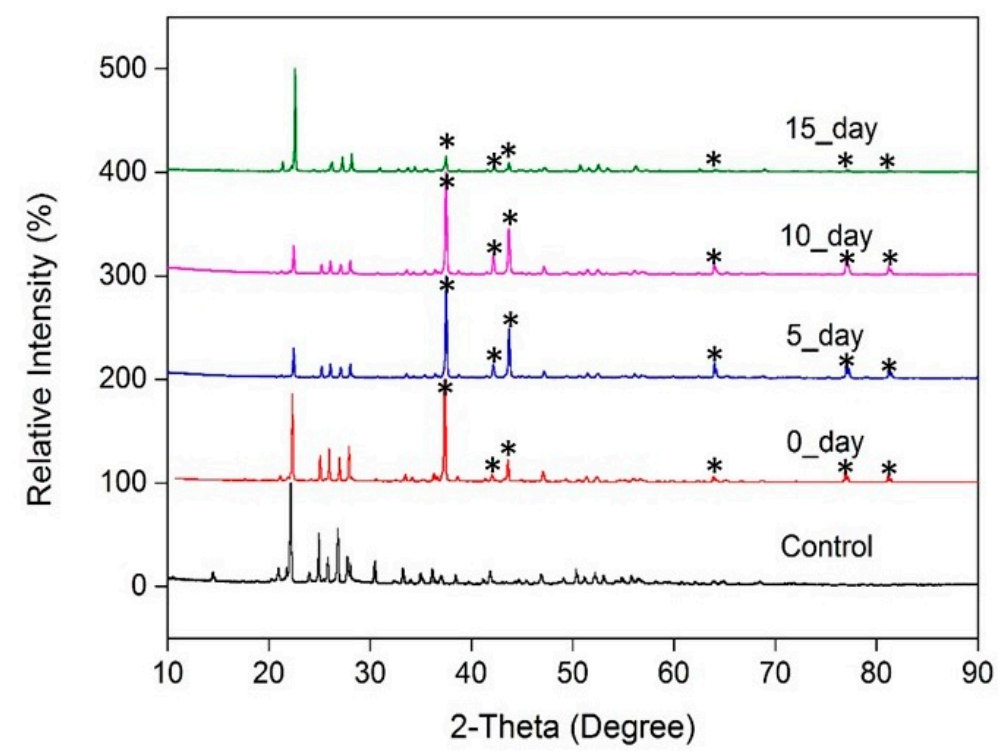

Figure 6. Powder X-ray diffraction (PXRD) patterns of the elemental sulfur (control), and sulfur supported-membranes for $0,5,10$, and 15 days. Peaks with asterisk $\left({ }^{*}\right)$ are related to the porous support and the aluminium holder; control data are provided in the ESI Section S2.3.

\subsection{Single-Gas Permeation Results}

Single-gas permeability measurements of sulfur thin-films were made using a dead-end filtration apparatus (Figure 1). The gas permeability of the first thin-film (thickness ca. $10 \mu \mathrm{m}$ ) sulfur membrane we studied was observed to creep over time (Table 1), with a major discontinuity occurring after 15 days. These results coincide with the creep observed in the PXRD results (Figure 6) and are likely linked to the reversion of polymeric sulfur to the $S_{8}$ allotrope. The observed gas permeabilities were low, even after the structural discontinuity, and suggest the thin films remained (Table 1).

Table 1. Single gas permeation for 3 runs.

\begin{tabular}{ccccccc}
\hline Gas & \multicolumn{2}{c}{ Run 1 } & \multicolumn{2}{c}{ Run 2 } & \multicolumn{2}{c}{ Run 3 } \\
\hline & Barrer & $\begin{array}{c}\mathbf{1 0}^{-\mathbf{1 6}} \\
\mathbf{m o l} \mathbf{m} /\left(\mathbf{m}^{\mathbf{3}} \cdot \mathbf{s} \cdot \mathbf{P a}\right)\end{array}$ & Barrer & $\begin{array}{c}\mathbf{1 0}^{-\mathbf{1 6}} \\
\mathbf{m o l} \cdot \mathbf{m} /\left(\mathbf{m}^{\mathbf{3}} \cdot \mathbf{s} \cdot \mathbf{P a}\right)\end{array}$ & Barrer & $\begin{array}{c}\mathbf{1 0}-\mathbf{1 6} \\
\mathbf{m o l} \cdot \mathbf{m} /\left(\mathbf{m}^{\mathbf{3}} \cdot \mathbf{s} \cdot \mathbf{P a}\right)\end{array}$ \\
\hline $\mathrm{C}_{2} \mathrm{H}_{4}$ & 0.26 & 0.9 & $0.90^{2}$ & $3^{2}$ & $0.84^{2}$ & $2.8^{2}$ \\
$\mathrm{CO}_{2}$ & 0.29 & 1.0 & $0.85^{2}$ & $2.8^{2}$ & $0.98^{2}$ & $3.3^{2}$ \\
$\mathrm{H}_{2}$ & $1.7^{2}$ & $4.4^{2}$ & $1.6^{2}$ & $5.4^{2}$ & $1.3^{2}$ & $4.4^{2}$ \\
$\mathrm{He}$ & 0.55 & 1.8 & 0.50 & 1.7 & $1.56^{2}$ & $5.2^{2}$ \\
$\mathrm{~N}_{2}$ & 0.38 & 1.3 & 0.41 & 1.4 & $0.60^{2}$ & $2.0^{2}$ \\
\hline
\end{tabular}

${ }^{1}$ Room temperature; initial pressure is ca. 1 bar, trans-membrane pressure is ca. 1 bar. ${ }^{2}$ Measurements recorded after the 15-day discontinuity.

Both before and after the ca. 15-day discontinuity in gas permeability properties related to the reversion of polymeric sulfur to the $S_{8}$ species, the permeability properties of sulfur thin-films were comparable to the common barrier materials cellophane (cellulose) and poly(tetrafluoroethylene) (PTFE) (Table 2). This suggests that if a mechanically robust form of polymeric sulfur could be generated, the resulting properties would be suitable for use as a commercial barrier material. 
Table 2. Gas permeability of sulfur compared to common barrier materials.

\begin{tabular}{ccccc}
\hline Gas & \multicolumn{2}{c}{ Sulfur } & Cellophane & Poly(tetrafluoroethylene) \\
\hline Reference & Pre-Discontinuity & Post-Discontinuity & {$[40]$} & [41] \\
\hline $\mathrm{H}_{2}$ & 0.71 & 1.6 & 0.43 & $13.27 \pm 4.84$ \\
$\mathrm{He}$ & 0.55 & 1.7 & 0.14 & 1.7 \\
$\mathrm{O}_{2}$ & & & 0.21 & $13.0 \pm 2.4$ \\
$\mathrm{~N}_{2}$ & 0.38 & 0.6 & 0.31 & 0.23 \\
$\mathrm{CO}_{2}$ & 0.29 & 0.9 & & \\
$\mathrm{C}_{2} \mathrm{H}_{4}$ & 0.26 & 0.9 & \\
\hline \multicolumn{5}{c}{ The units for all values reported are $10^{-16} \mathrm{~mol} \cdot \mathrm{m} /\left(\mathrm{m}^{3} \cdot \mathrm{s} \cdot \mathrm{Pa}\right)}$.
\end{tabular}

\section{Conclusions}

Thin films of sulfur have low permeabilities comparable to the common barrier materials cellophane and PTFE. The sulfur films were observed to suffer from aging linked to the reversion of polymeric sulfur to the thermodynamically stable $\mathrm{S}_{8}$ allotrope. This aging is associated with an increase in the permeability of all gases. This work provides base data to which further studies on S-derived low cost barrier materials may be compared. Due to the low commodity price of sulfur, there is promise that these materials could serve as low-cost barrier materials and we look forward to reporting those measurements in the near future.

Supplementary Materials: The following are available online at http://www.mdpi.com/2077-0375/9/6/72/s1, Contexualization of novelty statements and further experimental data. Figure S1: TGA data for sulfur powder (S8) using the mass at $50{ }^{\circ} \mathrm{C}$ as the reference for the relative mass calculation, Figure S2: DTA data for sulfur powder (S8) during the first cycle, Figure S3: PXRD of aluminium sample holder, Figure S4: PXRD of PES support.

Author Contributions: Conceptualization, M.G.C. and T.D.B.; methodology, M.G.C. and X.J.; investigation, X.J.; writing - original draft preparation, X.J.; writing_review and editing, M.G.C. and T.D.B. funding acquisition, M.G.C.

Funding: M.G.C. and X.J. gratefully acknowledge the MacDiarmid Institute for funding an RA position. T.D.B. would like to thank the Royal Society for a University Research Fellowship (UF150021), and the EPSRC (EP/R015481/1). T.D.B. would also like to thank the Royal Society for a Research Grant (RSG/R1/180395), and the University of Canterbury, Christchurch, New Zealand, for a University of Cambridge Visiting Canterbury Fellowship.

Acknowledgments: We acknowledge Matthew I. J. Polson for training of X. Jia on PXRD. We acknowledge Tom Hasell (University of Liverpool) for useful discussions.

Conflicts of Interest: The authors declare no conflict of interest.

\section{References}

1. Wu, X.; Smith, J.A.; Petcher, S.; Zhang, B.; Parker, D.J.; Griffin, J.M.; Hasell, T. Catalytic inverse vulcanization. Nat. Commun. 2019, 10, 647. [CrossRef] [PubMed]

2. Kutney, G. Sulfur: History, Technology, Applications \& Industry; ChemTec Publishing: Toronto, ON, Canada, 2007.

3. Merchant Research and Consulting. Sulfur: 2019 World Market Review and Forecast to 2028; Merchant Research \& Consulting Ltd.: Birmingham, UK, 2019.

4. Lagaron, J.M.; Catalá, R.; Gavara, R. Structural characteristics defining high barrier properties in polymeric materials. Mater. Sci. Technol. 2013, 20, 1-7. [CrossRef]

5. United States Geological Survey. Sulfur Statistics and Information. Available online: https://www.usgs.gov/ centers/nmic/sulfur-statistics-and-information (accessed on 20 May 2019).

6. Wooding, A.; Kavale, S.; MacRitchie, F.; Stoddard, F.; Wallace, A. Effects of nitrogen and sulfur fertilizer on protein composition, mixing requirements, and dough strength of four wheat cultivars. Cereal Chem. 2000, 77, 798-807. [CrossRef]

7. Yin, Y.X.; Xin, S.; Guo, Y.G.; Wan, L.J. Lithium-sulfur batteries: Electrochemistry, materials, and prospects. Angew. Chem. Int. Ed. 2013, 52, 13186-13200. [CrossRef] [PubMed] 
8. Ghosh, P.; Katare, S.; Patkar, P.; Caruthers, J.M.; Venkatasubramanian, V.; Walker, K.A. Sulfur vulcanization of natural rubber for benzothiazole accelerated formulations: From reaction mechanisms to a rational kinetic model. Rubber Chem. Technol. 2003, 76, 592-693. [CrossRef]

9. Meyer, B. Elemental sulfur. Chem. Rev. 1976, 76, 367-388. [CrossRef]

10. Lim, J.; Pyun, J.; Char, K. Recent approaches for the direct use of elemental sulfur in the synthesis and processing of advanced materials. Angew. Chem. Int. Ed. 2015, 54, 3249-3258. [CrossRef]

11. Worthington, M.J.; Kucera, R.L.; Chalker, J.M. Green chemistry and polymers made from sulfur. Green Chem. 2017, 19, 2748-2761. [CrossRef]

12. Boyd, D.A. Sulfur and its role in modern materials science. Angew. Chem. Int. Ed. 2016, 55, 15486-15502. [CrossRef]

13. Nguyen, T.B. Recent advances in organic reactions involving elemental sulfur. Adv. Synth. Catal. 2017, 359, 1066-1130. [CrossRef]

14. Chung, W.J.; Griebel, J.J.; Kim, E.T.; Yoon, H.; Simmonds, A.G.; Ji, H.J.; Dirlam, P.T.; Glass, R.S.; Wie, J.J.; Nguyen, N.A. The use of elemental sulfur as an alternative feedstock for polymeric materials. Nat. Chem. 2013, 5, 518-524. [CrossRef] [PubMed]

15. Griebel, J.J.; Glass, R.S.; Char, K.; Pyun, J. Polymerizations with elemental sulfur: A novel route to high sulfur content polymers for sustainability, energy and defense. Prog. Polym. Sci. 2016, 58, 90-125. [CrossRef]

16. Griebel, J.J.; Nguyen, N.A.; Namnabat, S.; Anderson, L.E.; Glass, R.S.; Norwood, R.A.; Mackay, M.E.; Char, K.; Pyun, J. Dynamic Covalent Polymers via Inverse Vulcanization of Elemental Sulfur for Healable Infrared Optical Materials. ACS Macro Lett. 2015, 4, 862-866. [CrossRef]

17. Xin, Y.; Peng, H.; Xu, J.; Zhang, J. Ultrauniform Embedded Liquid Metal in Sulfur Polymers for Recyclable, Conductive, and Self-Healable Materials. Adv. Funct. Mater. 2019, 29, 1808989. [CrossRef]

18. Parker, D.J.; Chong, S.T.; Hasell, T. Sustainable inverse-vulcanised sulfur polymers. RSC Adv. 2018, 8, 27892-27899. [CrossRef]

19. Eftekhari, A.; Kim, D.-W. Cathode materials for lithium-sulfur batteries: A practical perspective. J. Mater. Chem. A 2017, 5, 17734-17776. [CrossRef]

20. Zhu, J.; Zhu, P.; Yan, C.; Dong, X.; Zhang, X. Recent progress in polymer materials for advanced lithium-sulfur batteries. Prog. Polym. Sci. 2019, 90, 118-163. [CrossRef]

21. Chalker, J.M.; Worthington, M.J.H.; Lundquist, N.A.; Esdaile, L.J. Synthesis and Applications of Polymers Made by Inverse Vulcanization. Top. Curr. Chem. 2019, 377, 16. [CrossRef]

22. Hasell, T.; Parker, D.J.; Jones, H.A.; McAllister, T.; Howdle, S.M. Porous inverse vulcanised polymers for mercury capture. Chem. Commun. 2016, 52, 5383-5386. [CrossRef]

23. Worthington, M.J.H.; Kucera, R.L.; Albuquerque, I.S.; Gibson, C.T.; Sibley, A.; Slattery, A.D.; Campbell, J.A.; Alboaiji, S.F.K.; Muller, K.A.; Young, J.; et al. Laying Waste to Mercury: Inexpensive Sorbents Made from Sulfur and Recycled Cooking Oils. Chem. Eur. J. 2017, 23, 16219-16230. [CrossRef]

24. Crockett, M.P.; Evans, A.M.; Worthington, M.J.H.; Albuquerque, I.S.; Slattery, A.D.; Gibson, C.T.; Campbell, J.A.; Lewis, D.A.; Bernardes, G.J.L.; Chalker, J.M. Sulfur-Limonene Polysulfide: A Material Synthesized Entirely from Industrial By-Products and Its Use in Removing Toxic Metals from Water and Soil. Angew. Chem. Int. Ed. 2016, 55, 1714-1718. [CrossRef] [PubMed]

25. Lundquist, N.A.; Worthington, M.J.H.; Adamson, N.; Gibson, C.T.; Johnston, M.R.; Ellis, A.V.; Chalker, J.M. Polysulfides made from re-purposed waste are sustainable materials for removing iron from water. RSC Adv. 2018, 8, 1232-1236. [CrossRef]

26. Deng, Z.; Hoefling, A.; Théato, P.; Lienkamp, K. Surface Properties and Antimicrobial Activity of Poly(sulfur-co-1,3-diisopropenylbenzene) Copolymers. Macromol. Chem. Phys. 2018, 219, 1700497. [CrossRef]

27. Sandrolini, F.; Manzi, S.; Andrucci, A. Sulfur-polymer matrix composites from particulate wastes: A sustainable route to advanced materials. Compos. Part A Appl. Sci. Manuf. 2006, 37, 695-702. [CrossRef]

28. Griebel, J.J.; Namnabat, S.; Kim, E.T.; Himmelhuber, R.; Moronta, D.H.; Chung, W.J.; Simmonds, A.G.; Kim, K.-J.; van der Laan, J.; Nguyen, N.A.; et al. New Infrared Transmitting Material via Inverse Vulcanization of Elemental Sulfur to Prepare High Refractive Index Polymers. Adv. Mater. 2014, 26, 3014-3018. [CrossRef]

29. Salman, M.K.; Karabay, B.; Karabay, L.C.; Cihaner, A. Elemental sulfur-based polymeric materials: Synthesis and characterization. J. Appl. Polym. Sci. 2016, 133, 43655. [CrossRef]

30. Namnabat, S.; Gabriel, J.J.; Pyun, J.; Norwood, R.A.; Dereniak, E.L.; Van Der Laan, J. Sulfur Copolymers for Infrared Optical Imaging; SPIE: San Diego, CA, USA, 2014; Volume 9070. 
31. Mann, M.; Kruger, J.E.; Andari, F.; McErlean, J.; Gascooke, J.R.; Smith, J.A.; Worthington, M.J.H.; McKinley, C.C.C.; Campbell, J.A.; Lewis, D.A.; et al. Sulfur polymer composites as controlled-release fertilisers. Org. Biomol. Chem. 2019, 17, 1929-1936. [CrossRef]

32. Worthington, M.J.H.; Shearer, C.J.; Esdaile, L.J.; Campbell, J.A.; Gibson, C.T.; Legg, S.K.; Yin, Y.; Lundquist, N.A.; Gascooke, J.R.; Albuquerque, I.S.; et al. Sustainable Polysulfides for Oil Spill Remediation: Repurposing Industrial Waste for Environmental Benefit. Adv. Sustain. Syst. 2018, 2, 1800024. [CrossRef]

33. Massey, L.K. Introduction. In Permeability Properties of Plastics and Elastomers, 2nd ed.; Massey, L.K., Ed.; William Andrew Publishing: Norwich, NY, USA, 2003; pp. 1-56.

34. Lee, W.M. Selection of barrier materials from molecular structure. Polym. Eng. Sci. 1980, 20, 65-69. [CrossRef]

35. Je, S.H.; Buyukcakir, O.; Kim, D.; Coskun, A. Direct Utilization of Elemental Sulfur in the Synthesis of Microporous Polymers for Natural Gas Sweetening. Chem 2016, 1, 482-493. [CrossRef]

36. Zhou, J.; Mok, M.M.; Cowan, M.G.; McDanel, W.M.; Carlisle, T.K.; Gin, D.L.; Noble, R.D. High-permeance room-temperature ionic-liquid-based membranes for $\mathrm{CO}_{2} / \mathrm{N}_{2}$ separation. Ind. Eng. Chem. Res. 2014, 53, 20064-20067. [CrossRef]

37. Cowan, M.G.; Masuda, M.; McDanel, W.M.; Kohno, Y.; Gin, D.L.; Noble, R.D. Phosphonium-based poly(Ionic liquid) membranes: The effect of cation alkyl chain length on light gas separation properties and Ionic conductivity. J. Membr. Sci. 2016, 498, 408-413. [CrossRef]

38. Crapanzano, L. Polymorphism of Sulfur: Structural and Dynamical Aspects. Ph.D. Thesis, Université Joseph-Fourier, Grenoble, France, 2006.

39. Cataldo, F. A study on the structure and properties of polymeric sulfur. Die Angew. Makromol. Chem. 1997, 249, 137-149. [CrossRef]

40. Morris, B.A. 4-Commonly Used Resins and Substrates in Flexible Packaging. In The Science and Technology of Flexible Packaging; Morris, B.A., Ed.; William Andrew Publishing: Oxford, UK, 2017; pp. 69-119.

41. Sebők, B.; Schülke, M.; Réti, F.; Kiss, G. Diffusivity, permeability and solubility of $\mathrm{H}_{2}, \mathrm{Ar}, \mathrm{N}_{2}$, and $\mathrm{CO}_{2}$ in poly(tetrafluoroethylene) between room temperature and $180{ }^{\circ} \mathrm{C}$. Polym. Test. 2016, 49, 66-72. [CrossRef]

(C) 2019 by the authors. Licensee MDPI, Basel, Switzerland. This article is an open access article distributed under the terms and conditions of the Creative Commons Attribution (CC BY) license (http://creativecommons.org/licenses/by/4.0/). 